\title{
Effects of Antibiotic, Probiotic and Prebiotic Supplementation in Broiler Diets on Performance Characteristics and Apparent Nutrient Digestibility
}

\section{${ }^{1}$ ALONGE, EO; ${ }^{1}$ ERUVBETINE, D; ${ }^{1}$ IDOWU, OMO; ${ }^{3}$ OBADINA, AO; ${ }^{*}$ OLUKOMAIYA, OO; ${ }^{4}$ OMOTAINSE, OS; ${ }^{5}$ AHMAD, FH, ${ }^{6}$ ABIOLA, YO}

\author{
${ }^{I}$ Department of Animal Nutrition, College of Animal Science and Livestock Production, Federal University of Agriculture, P.M.B. 2240, \\ Abeokuta, Nigeria \\ ${ }^{2}$ Department of Animal Production and Health, College of Animal Science and Livestock Production, Federal University of Agriculture, \\ P.M.B. 2240, Abeokuta, Nigeria \\ ${ }^{3}$ Department of Food Science and Technology, College of Food Sciences and Human Ecology, Federal University of Agriculture, P.M.B. \\ 2240, Abeokuta, Nigeria \\ ${ }^{4}$ Department of Veterinary Pathology, College of Veterinary Medicine, Federal University of Agriculture, P.M.B. 2240, Abeokuta, Nigeria \\ ${ }^{5}$ Department of Zoology, Faculty of Science, Bayero University, P.M.B. 3011, Kano, Nigeria \\ ${ }^{6}$ Department of Agricultural Engineering, Faculty of Agricultural and Environmental Sciences, Szent Istvan University, 2100 Godollo, Pater \\ Karoly utca 1, Hungary \\ *Corresponding Author's e-mail: oladapooluwaseye@ymail.com
}

\begin{abstract}
A total of 180-day-old Arbor Acres broiler chicks were used to determine the effects of antibiotic, probiotic and prebiotic supplementation in broiler diets on performance characteristics and apparent nutrient digestibility in an 8-week feeding trial. The birds were randomly allotted to 5 dietary treatments including control diet (basal diet without additives), OXYT diet (basal diet with $600 \mathrm{ppm}$ of the antibiotic oxytetracycline), GRO-UP diet (basal diet with $500 \mathrm{ppm}$ probiotic), and MOS-500 or MOS-1000 diets (basal diet with 500 or $1000 \mathrm{ppm}$ mannan oligosaccharide prebiotic, respectively) with 3 replicates of 12 birds each. No significant difference ( $P>0.05)$ was observed in the performance of broiler chickens except for reduction in mortality in the birds fed with feed additives. There were significant $(\mathrm{P}<0.05)$ differences in the apparent nutrient digestibility at the end of weeks 4 and 8 . Inclusion of dietary prebiotic and probiotic had no significant effect on broiler performance but reduced mortality rate and enhanced apparent nutrient digestibility.
\end{abstract}

DOI: https://dx.doi.org/10.4314/jasem.v21i7.13

Copyright (C) 2017 Alonge et al. This is an open access article distributed under the Creative Commons Attribution License (CCL), which permits unrestricted use, distribution, and reproduction in any medium, provided the original work is properly cited

Received 10 September 2017; received in revised form 30 October 2017; accepted 02 December 2017

Keywords: antibiotic, probiotic, prebiotic, broilers, performance, nutrient digestibility

Nutrition plays an important role in maintaining animal health and prevention of various diseases (Surai, 2002). Feed additives are products used in animal nutrition for purposes of improving the quality of feed and the quality of food from animal origin or to improve the animal performance and health (Hashemi and Davoodi, 2010). Antibiotics as feed additives have been used for many years in poultry diets (Engberg et al., 2000). Due to the potential of bacterial resistance and antibiotic residues in animal products (Nasir and Grashorn, 2006), attempts are being made to replace them with prebiotics and probiotics (Goodarzi and Nanekarani, 2014). Probiotics have been reported to have favourable effects on performance (Santin et al., 2001). Their mode of action includes competitive exclusion (Berchieri et al., 2006), microbial antagonism (Mountzouris et al., 2006) and immune modulation (Lan et al., 2005). Prebiotics are food ingredients that stimulate selective growth and activity of beneficial microorganisms in the gut and thereby benefit health (Cummings and Macfarlane, 2002).

They also enhance digestibility and performance parameters by creating favourable conditions for beneficial bacteria (Steiner, 2006). Supplementation with probiotics and prebiotics can improve the performance of broiler chickens (Bozkurt et al., 2014). However, there are still indications that the results of using probiotic and prebiotic in poultry diets are quite inconsistent. Hence, the current study is to determine the effects of antibiotic, probiotic and prebiotic supplementation in broiler diets on performance characteristics and apparent nutrient digestibility.

\section{MATERIALS AND METHODS}

The experiment was conducted at the Poultry Unit of Directorate of University Farms, Federal University of Agriculture, Abeokuta, Nigeria.

One hundred and eighty day-old Arbor Acres broiler chicks obtained from a commercial hatchery were weighed and randomly divided into five dietary treatments with three replicates of 12 birds each. Five experimental diets were formulated at starter and finisher phases to include control diet (basal diet without additives), OXYT diet (basal diet with 600 ppm of the antibiotic oxytetracycline), GRO-UP diet (basal diet with $500 \mathrm{ppm}$ probiotic), and MOS-500 or MOS-1000 diets (basal diet with 500 or 1000 ppm 
mannan oligosaccharide prebiotic, respectively). The birds were reared intensively on deep litter housing system and brooding was done for 2 weeks. Temperature was maintained at a stable ambient condition of $30.2^{\circ} \mathrm{C}$ after brooding and throughout the study period.

Table 1: Ingredients and chemical composition of basal diets

\begin{tabular}{lll}
\multicolumn{3}{c}{ (As-fed basis) } \\
\hline Ingredients (\%) & $\begin{array}{l}\text { Starter } \\
\text { (Weeks 0-4) }\end{array}$ & $\begin{array}{l}\text { Finisher } \\
\text { (Weeks 4-8) }\end{array}$ \\
\hline Maize & 50.66 & 55.00 \\
Wheat offal & 5.00 & 6.00 \\
Fish meal (72\%) & 3.00 & 2.00 \\
Soybean meal & 24.24 & 18.00 \\
Groundnut cake & 10.00 & 13.00 \\
Palm kernel cake & 3.00 & - \\
Bone meal & 2.00 & 2.00 \\
Oyster shell & 1.00 & 2.75 \\
Lysine & 0.10 & 0.20 \\
Methionine & 0.25 & 0.30 \\
*Premix & 0.50 & 0.50 \\
Salt (NaCl) & 0.25 & 0.25 \\
Total & 100.00 & 100.00 \\
Calculated analysis & & \\
Metabolizable energy (Kcal/kg) & 2856 & 2911 \\
Crude protein (\%) & 23.01 & 20.71 \\
Lysine (\%) & 1.30 & 1.20 \\
Methionine (\%) & 0.60 & 0.60 \\
Methionine + Cystine (\%) & 1.00 & 0.97 \\
Available phosphorus (\%) & 0.50 & 0.50 \\
Calcium (\%) & 1.20 & 1.80 \\
\hline
\end{tabular}

*A kilogramme premix contains Vit. A: 10000000 IU, Vit. $D_{3}$ : 2500000 IU, Vit. E: $20000 \mathrm{mg}$, Vit. $\mathrm{K}_{3}: 3000 \mathrm{mg}$, Vit. B: 30000 mg, Vit. $B_{3}: 3000 \mathrm{mg}$, Vit. $B_{2}: 7000 \mathrm{mg}$, Vit. $B_{6}: 5000 \mathrm{mg}$, Vit. $B_{12}$ : $25 \mathrm{mg}$, Panthotenic acid: $10000 \mathrm{mg}$, Folic acid: $800 \mathrm{mg}$, Biotin: 50mg, Manganese: $80000 \mathrm{mg}$, Iron: $40000 \mathrm{mg}$, Zinc: $60000 \mathrm{mg}$, Copper: $8000 \mathrm{mg}$, Cobalt: $250 \mathrm{mg}$, Iodine: $1000 \mathrm{mg}$, Selenium (1\%), $150 \mathrm{mg}$, Choline: $200000 \mathrm{mg}$ and Antioxidant: $100000 \mathrm{mg}$.
The composition of the experimental basal diets is presented in Table 1. Data on performance was collected weekly. At the end of weeks 4 and 8, four birds per replicate (making a total of 12 birds per treatment) were selected and arranged in clean, separate and disinfected metabolic cages. Three days of acclimatization were allowed prior to digestibility study. A known weight of feed, which matched previous daily feed intake, was fed during the metabolic trial. Excreta were collected daily for a period of three days. The daily excreta voided for each bird was dried overnight (at $55^{\circ} \mathrm{C}$ ) while total collections per bird were pooled at the end of the 3day metabolic trial. Dried excreta samples were grounded and analyzed to determine the proximate composition according to the method of AOAC (1990).

Statistical analysis: Data obtained from the trial were subjected to Analysis of Variance (ANOVA) in a Completely Randomized Design (CRD) using SAS (2003). Significant means among variables were separated using Duncan's Multiple Range Test.

\section{RESULTS AND DISCUSSION}

The effects of antibiotic, probiotic and prebiotic supplementation in broiler diets on performance are presented in Table 2. Mortality was lowest $(\mathrm{P}<0.05)$ in the birds fed MOS (500 and 1000 ppm) while those fed on GRO-UP recorded the highest $(\mathrm{P}<0.05)$ mortality. At the finisher phase, the average final weight of birds fed diets supplemented with OXYT, GRO-UP and MOS (500 ppm) compared favourably $(\mathrm{P}>0.05)$ with that of control. Mortality was lowest $(\mathrm{P}<0.05)$ in birds fed OXYT, GRO-UP and MOS (1000 ppm).

Table 2: Effects of antibiotic, probiotic and prebiotic supplementation in broiler diets on performance characteristics

\begin{tabular}{|c|c|c|c|c|c|c|}
\hline Parameters & Control & OXYT & GRO-UP & MOS (500 ppm) & MOS (1000 ppm) & SEM \\
\hline \multicolumn{7}{|l|}{ Weeks 0-4 } \\
\hline Initial weight (g/bird) & 37.43 & 37.33 & 37.58 & 36.79 & 37.83 & 0.36 \\
\hline Final weight (g/bird) & 766.67 & 728.00 & 798.00 & 753.00 & 737.33 & 10.32 \\
\hline Weight gain (g/bird) & 729.24 & 690.67 & 760.42 & 716.21 & 699.50 & 10.35 \\
\hline Total feed intake (g) & 1711.84 & 1597.29 & 1662.13 & 1751.72 & 1736.42 & 23.30 \\
\hline Feed conversion ratio & 2.35 & 2.31 & 2.19 & 2.46 & 2.48 & 0.05 \\
\hline Mortality (\%) & $5.56^{\mathrm{b}}$ & $5.56^{\mathrm{b}}$ & $8.33^{\mathrm{a}}$ & $2.78^{\mathrm{c}}$ & $2.78^{\mathrm{c}}$ & 1.36 \\
\hline \multicolumn{7}{|l|}{ Weeks 4-8 } \\
\hline Initial weight (g/bird) & 766.67 & 728.00 & 798.00 & 753.00 & 737.33 & 10.32 \\
\hline Final weight (g/bird) & $2466.67^{\mathrm{a}}$ & $2366.67^{\mathrm{ab}}$ & $2400.00^{\mathrm{ab}}$ & $2366.67^{\mathrm{ab}}$ & $2266.67^{b}$ & 26.67 \\
\hline Weight gain/bird (g/bird) & 1700.00 & 1638.67 & 1602.00 & 1613.67 & 1529.34 & 24.73 \\
\hline Total feed intake $(\mathrm{g})$ & 5644.33 & 5305.67 & 5424.33 & 5518.67 & 5519.02 & 53.94 \\
\hline Feed conversion ratio & 3.34 & 3.25 & 3.39 & 3.43 & 3.61 & 0.06 \\
\hline Mortality (\%) & $8.33^{\mathrm{a}}$ & $2.78^{\mathrm{c}}$ & $2.78^{\mathrm{c}}$ & $5.56^{\mathrm{b}}$ & $2.78^{\mathrm{c}}$ & 0.13 \\
\hline
\end{tabular}

The effects of antibiotic, probiotic and prebiotic supplementation in broiler diets on apparent nutrient digestibility are shown in Table 3. At week 4, the control group had the lowest dry matter, crude protein, ash and nitrogen free extract contents when compared to the feed additive groups. At week 8 , birds fed OXYT, GRO-UP and MOS (500 ppm) supplemented diets had statistically similar value $(\mathrm{P}<0.05)$ for dry matter while birds fed MOS $(1000$ ppm) supplemented diets had the least dry matter. Crude protein was highest in birds fed GRO-UP and MOS (500 ppm). Diet supplemented with MOS 
(1000 ppm) had the highest crude fibre. GRO-UP and MOS (1000 ppm) diets had the highest nitrogen free extract when compared to other treatments. The performance of birds fed with feed additives did not differ significantly from the control throughout the study which agrees with the report of Ravangard et al. (2017) who observed similar trend. In contrast,
Murshed and Abudabos (2015) found that dietary inclusion of probiotic and prebiotic had beneficial effects on body weight gain and feed conversion ratio during the first two weeks of age.

Table 3: Effects of antibiotic, probiotic and prebiotic supplementation in broiler diets on apparent nutrient digestibility

\begin{tabular}{|c|c|c|c|c|c|c|}
\hline Parameters & Control & OXYT & GRO-UP & $\begin{array}{l}\text { MOS }(500 \\
\text { ppm) }\end{array}$ & $\begin{array}{l}\text { MOS }(1000 \\
\text { ppm) }\end{array}$ & SEM \\
\hline \multicolumn{7}{|l|}{ Week 4} \\
\hline Dry matter $(\%)$ & $80.45^{\mathrm{c}}$ & $84.16^{\mathrm{ab}}$ & $85.78^{\mathrm{ab}}$ & $87.11^{\mathrm{a}}$ & $82.92^{\mathrm{b}}$ & 0.67 \\
\hline Crude protein $(\%)$ & $74.51^{\mathrm{c}}$ & $78.34^{\mathrm{a}}$ & $79.93^{\mathrm{a}}$ & $79.93^{\mathrm{a}}$ & $78.19^{\mathrm{b}}$ & 0.82 \\
\hline Ether extract (\%) & 78.49 & 79.13 & 77.32 & 78.52 & 78.12 & 0.38 \\
\hline Ash $(\%)$ & $70.16^{\mathrm{b}}$ & $74.93^{\mathrm{ab}}$ & $74.01^{\mathrm{ab}}$ & $76.14^{\mathrm{a}}$ & $76.32^{\mathrm{a}}$ & 0.94 \\
\hline Crude fibre (\%) & 61.53 & 60.15 & 61.94 & 59.74 & 62.13 & 0.85 \\
\hline Nitrogen Free Extract (\%) & $73.11^{\mathrm{c}}$ & $80.11^{\mathrm{a}}$ & $82.34^{\mathrm{a}}$ & $79.32^{\mathrm{ab}}$ & $76.14^{\mathrm{b}}$ & 0.82 \\
\hline \multicolumn{7}{|l|}{ Week 8} \\
\hline Dry matter $(\%)$ & $83.22^{\mathrm{ab}}$ & $87.13^{\mathrm{a}}$ & $86.68^{\mathrm{a}}$ & $85.75^{\mathrm{ab}}$ & $80.78^{\mathrm{b}}$ & 0.86 \\
\hline Crude protein $(\%)$ & $72.50^{\mathrm{b}}$ & $74.33^{\mathrm{b}}$ & $81.11^{\mathrm{a}}$ & $81.43^{\mathrm{a}}$ & $73.77^{\mathrm{b}}$ & 0.94 \\
\hline Ether extract (\%) & 79.30 & 80.25 & 82.33 & 78.60 & 81.05 & 0.46 \\
\hline Ash $(\%)$ & 63.14 & 73.33 & 70.53 & 71.68 & 73.14 & 0.69 \\
\hline Crude fibre (\%) & $60.14^{\mathrm{c}}$ & $61.53^{\mathrm{c}}$ & $61.07^{\mathrm{c}}$ & $63.06^{\mathrm{b}}$ & $69.30^{\mathrm{a}}$ & 0.67 \\
\hline Nitrogen Free Extract (\%) & $77.44^{\mathrm{b}}$ & $78.13^{\mathrm{b}}$ & $80.44^{\mathrm{a}}$ & $79.91^{\mathrm{b}}$ & $80.06^{\mathrm{a}}$ & 0.91 \\
\hline
\end{tabular}

Oxytetracycline (antibiotics); GRO-UP (probiotics); MOS: Mannan oligosaccharide (prebiotics); SEM: Standard error of mean

The results of using probiotics and prebiotics in poultry diets are inconsistent. Well-nourished healthy chicks may not respond to growth promoting supplements when they are housed in clean, disinfected conditions and at a moderate stocking density (Botsoglou et al., 2004). Mortality was lowest in birds fed diets with MOS 500 and 1000 ppm at the starter phase which agrees with the report of Hooge (2003) that MOS has mortality lowering ability. The reduction in mortality observed at the finisher phase in birds fed dietary feed additives may be attributed to boost in body defense against diseases and gut microbial balance. The observed improvement in apparent nutrient digestibility in diets supplemented with feed additives at the starter phase agrees with the finding of Yang et al. (2008) who reported that feed additives could affect nutrient utilization of birds. However, at the finisher phase, diets with MOS-1000 had the lowest dry matter, highest crude fibre and both GRO-UP and MOS-1000 diets, had the highest nitrogen free extracts. Kumprecht and Zobac (1997) showed that total tract digestibility of fibre was increased by MOS, but the digestibility of nitrogen free extract was not affected.

Conclusion: Inclusion of dietary prebiotic and probiotic had no significant effect on broiler performance but reduced mortality rate and enhanced apparent nutrient digestibility.

\section{REFERENCES}

AOAC (1990). Association of Official Analytical Chemists. Official Methods of Analysis. 15th Edition, Washington, D.C.
Berchieri, A; Sterzo, E; Paiva, J; Luckstadt, C; Beltran, R (2006). The use of a defined probiotic product (Biomin ${ }^{\circledR}$ PoultryStar) and organic acids to control Salmonella enteritidis in broiler chickens. 9th International Seminar on Digestive Physiology in the Pig. 2: 217-219.

Botsoglou, NA; Christaki, E; Florou-Paneri, P; Giannenas, I; Papageorgiou, G; Spais, AB (2004). The effect of a mixture of herbal essential oils or $\alpha$-tocopheryl acetate on performance parameters and oxidation of body lipid in broilers. South Afr. J. Anim. Sci., 34 (1): 52-61.

Bozkurt, M; Aysul, N; Küçükyilmaz, K; Aypak, S; Ege, G; Çatli, AU; Çınar, M (2014). Efficacy of in-feed preparations of an anticoccidial, multienzyme, prebiotic, probiotic, and herbal essential oil mixture in healthy and Eimeria spp.infected broilers. Poult. Sci., 93(2): 389-399.

Cummings, JH; Macfarlane, GT (2002). Gastrointestinal effects of prebiotics, Br. J. Nutr., 87 (2):145-151.

Engberg, RM; Hedemann, MS; Leser, TD; Jensen, BB (2000). Effect of zinc bacitracin and salinomycin on intestinal microflora and performance of broilers, Poult, Sci., 79:13111319.

Goodarzi, M; Nanekarani, S (2014). Effect of onion extract in drinking water on performance and carcass traits in broiler chickens. In: 2014 
International Conference on Agricultural and Biosystem Engineering. IERI Procedia, 8: 107 112 .

Hashemi, SR; Davoodi, H (2010). Phytogenics as new class of feed additive in poultry industry. $J$. Anim. Vet. Adv., 9 (17): 2295-2304.

Hooge, DM (2003). Dietary mannan oligosaccharide improves broiler performance. World Poultry. 19: 14-15.

Kumprecht, I; Zobac, F (1997). The effect of mannan oligosaccharides in feed mixtures on the performance of broilers. Zivocisna Vyroba, 42: 117-124.

Lan, Y; Verstegen, MWA; Taminga, S; Williams, BA (2005). The role of the commensal gut microbial community in broiler chickens, World's Poult. Sci. J., 61: 95-104.

Mountzouris, KC; Beneas, H; Tsirtsikos, P; Kalamara, E; Fegeros, K (2006). Efficacy of a new multi-strain probiotic product in promoting broiler performance and modulating the composition and activities of cecal microflora, International Poultry Science Forum, Atlanta, Georgia. 59 p.

Murshed, MA; Abudabos, AM (2015). Effects of the dietary inclusion of a probiotic, a prebiotic or their combinations on the growth performance of broiler chickens, Rev. Bras. Ciênc. Avíc., 17: 99103.

Nasir, Z; Grashorn, MA (2006). Use of black cumin (Nigella sativa) as alternative to antibiotics in poultry diets, Proceedings of the 9th Tagung schweine-und geflügelernährung, Halle, Germany, 210-213 pp.

Ravangard, AH; Houshmand, M; Khajavi, M; Naghiha, R (2017). Performance and cecal bacteria counts of broilers fed low protein diets with and without a combination of probiotic and prebiotic. Rev. Bras. Ciênc. Avíc. 19: 75-82.

Santin, E; Maoirka, A; Macari, M; Grecco, M; Sanchez, JC; Okada, TM; Myasaka, AM (2001). Performance and intestinal mucosa development of broiler chickens fed diets containing Saccharomyces cerevisiae cell wall. J. Appl. Poultry Res., 10: 236-244.

SAS (2003). SAS/STAT ${ }^{(\mathrm{R})}$ User's Guide: Statistics. SAS Institute Inc., Cary, North Carolina, USA

Steiner, T (2006). Managing gut health: natural growth promoters as a key to animal performance. Nottingham University Press, Nottingham, UK.

Surai, PF (2002). Natural antioxidants in avian nutrition and reproduction. Nottingham University Press, Nottingham, UK.

Yang, Y; Iji, PA; Choct, M (2008). Effects of mannan oligosaccharide on growth performance, the development of gut microflora and gut function of young birds given cereal-based diets. AsianAustralas. J. Anim. Sci., 20:1084-1091.

Yang, Y; Iji, PA; Choct, M (2009). Dietary modulation of gut microflora in broiler chickens: a review of the role of six kinds of alternatives to in-feed antibiotics. World's Poult. Sci. J., 65(1) :97-114. 